\title{
Sicily, the Classical Tradition and Interpretative Possibilities in John Barclay's Argenis
}

\author{
Ruth Parkes ${ }^{1}$ (D)
}

Accepted: 16 October 2021 / Published online: 29 November 2021

(C) The Author(s) 2021

\begin{abstract}
This article explores reasons for the choice of Sicily as the main backdrop for John Barclay's 1621 Neo-Latin novel Argenis. It suggests that the selection of Sicily is driven in part by the interpretative possibilities raised by this location, in particular, those fuelled by controversies regarding the rational and mythic which were attached to the island. It focusses on the rationalizing and mythic approaches associated with Sicily in the classical and post-classical tradition in the areas of volcanic activity and the discovery of gigantic bones. By means of a close reading of the episode in which King Meleander entertains Radirobanes in camp, followed by a wider discussion of the flaws of Meleander and Radirobanes and the theme of interpretation in the novel, it explores how Barclay exploits such approaches to showcase the failures of these leaders. It also dismisses the idea that the Argenis has a controlling divine framework which would run counter to the novel's interest in the potentiality of interpretation.
\end{abstract}

John Barclay was born in France to a Catholic French mother and a Catholic Scottish father, William Barclay. He moved to the Protestant court of King James I in 1605 , possibly passing as conforming or actually converting to Protestantism. ${ }^{1} \mathrm{He}$ left in 1615, however, after a decade of poetic and diplomatic activity there and appeared in Rome in 1616. He was in the employment of the papal Borghese and Barberini families in 1621 when he wrote his Neo-Latin novel Argenis, the subject of this article. He dedicated the novel, however, to the French king Louis XIII (who was then thirteen years old), presumably with a view to other future sources of patronage. The Argenis has often attracted notice for its engagement with a variety of contemporary European debates, frequently in a dialogic way. ${ }^{2}$ It has also gained

\footnotetext{
${ }^{1}$ For this, see M. Growhoski, “"A Most Dangerous Rudeness”: Anti-Populism and the Literary Justification of Absolutism in the Fiction of John Barclay (1582-1621)', in Democracy and Anti-Democracy in Early Modern England, 1603-1689, ed. C. Cuttica and M. Peltonen, Leiden, 2019, pp. 113-31 (115).

${ }^{2}$ See, e,g. the presentation of different views on the treatment of the religious minority, the Hyperephanians, at John Barclay, Argenis, ed. M. Riley and D. Pritchard Huber, 2 vols, Assen, 2004 [henceforth R-H], pp. 267-74 (II.5.1-7); and on raising taxation, ibid., pp. 732-44 (IV.18.1-16).
}

Ruth Parkes

r.parkes@uwtsd.ac.uk

1 University of Wales Trinity Saint David, Lampeter, Wales, UK 
attention for the complexities of its plot, which is propelled by the struggles of four suitors (Poliarchus, Lycogenes, Radirobanes and Archombrotus) to marry the titular heroine, daughter of the Sicilian king Meleander. The novel closes with the marriage alliance of Argenis and Poliarchus (whose friendship had started when Poliarchus was disguised as a female, Theocrine). This union ends the rise of Poliarchus, whom the start of the novel had shown on the run from Lycogenes's men, sent at the behest of Meleander, and seeking refuge in a vault.

The focus of this article is the novel's Sicilian locale. Although the narrative, which unfolds in a vaguely classical and pre-Roman time, includes other places (notably Mauritania), Sicily serves as the main setting. ${ }^{3}$ Indeed, this location is signalled in the opening scene in which the Mauritanian-born Archombrotus lands at the mouth of the river Gela and is immediately called on to aid Poliarchus. As Elizabeth Bearden has shown, the inclusion of Mauritania is readily explainable through the novel's interest in Afro-European relations and the aim of showing, against the backdrop of a 'faltering Holy Roman Empire', how affinities can surpass cultural divides. ${ }^{4}$ The inclusion also conveniently facilitates the exploitation of the parts of Virgil's Aeneid set in North Africa: for Barclay's aspiring 'epic in prose' holds the Aeneid as one of its key poetic intertexts, alongside Ovid's Metamorphoses. ${ }^{5}$ By contrast, Sicily, which is the dominant topographical setting, has not yet received

\footnotetext{
${ }^{3}$ The pre-Roman chronology is signalled at R-H, p. 102 (I.1.1): 'Not yet had the world paid homage to Rome, not yet had the ocean yielded to the Tiber' ('Nondum orbis adoraverat Romam, nondum Oceanus decesserat Tibri'). Translations are my own. The characters are said to speak Greek rather than Latin, though reference is made to Poliarchus's written Italian: R-H, p. 494 (III.9.7). For other countries involved, see J. IJsewijn, 'John Barclay and His Argenis. A Scottish Neo-Latin Novelist', Humanistica Lovaniensia, 32, 1983, pp. 1-27 (9).

${ }^{4}$ The quotation is taken from E. B. Bearden, The Emblematics of the Self: Ekphrasis and Identity in Renaissance Imitations of Greek Romances, Toronto etc., 2013, p. 157; see also ibid., pp. 143-57.

${ }^{5}$ For Ovid, see below. For Virgil, see IJsewijn 'John Barclay' (n. 3 above), p. 17: 'After all, the early novel was conceived of as an epic in prose and therefore Virgil was the most obvious model'. See C. Connors, 'Metaphor and Politics in John Barclay's Argenis', in Metaphor and the Ancient Novel, ed. S. J. Harrison et al. (Ancient Narrative Supplementum 4), Groningen, 2005, pp. 245-74 (262-5), for engagement with the Carthaginian episodes of Virgil's Aeneid. Barclay also looks to other classical epic poets such as Lucan: the inclusion of an ill-omened extispicy (R-H, p. 264, [II.4.4]), comets (R-H, p. 264 [II.4.5]) and Aetna (R-H, p. 264 [II.4.5]) in the list of portents recalls the omens of Lucan's first book (cf. the comet at Bellum civile, I.529-30, the eruption of Aetna, I.545-7 and the extispicy, I.617-36), thereby underscoring the civil aspect of the strife in Sicily (the stress on disordered entrails and head in the liver at R-H, p. 264 [II.4.4] suggests engagement with Lucan, rather than Lucan's Virgilian model passage, which also features comets at Georgics, I.488, Aetna at I.471-3 and entrails at I.484). Barclay also draws on Statius (R-H, p. 4). For the Achilleid, see below. For the Thebaid (on which Barclay had produced commentary in 1601), see, e.g. Tisiphone's summoning of Megaera as part of her instigation of Polynices's and Eteocles's duel in the civil war: Statius, Thebaid, XI.64-5: 'And she raises a serpent from her hair with a long hiss - an indubitable sign for the infernal regions' ('Elysiis signum indubitabile regnis / crinalem attollit longo stridore cerasten'). This is reworked in the Statian-inspired verses of Nicopompus, where the Furies raise Lycogenes as a 'deadly omen' ('signum exitiabile'), at R-H, p. 122 (I.3.9): 'as first they raise a horned serpent from their brow' ('ceu primum a fronte Cerasten /Attollunt'). IJsewijn, 'John Barclay' (n. 3 above), p. 22, perceives engagement with Homer's Iliad in Archombrotus's recollection of how Meleander had allowed his armour to be adopted in battle by him, as Achilles had done with Patroclus (cf. Homer, Iliad, XVI.129; see R-H, p. 422 [III.1.9]: 'The gods have done well that, luckier than Patroclus, I have deceived with greater arms' ['Dii bene quod Patroclo felicior maioribus armis fefelli']).
} 
the attention it deserves. One can see the attraction of an island location for its potential to incorporate the kind of content, like dramatic descriptions of sea journeys and pirate threats, which was favoured by the ancient novel tradition to which the Argenis is heir. ${ }^{6}$ Furthermore, an island backdrop also lends itself to inclusion of storms, which appear not only on the physical level but also on the metaphorical plane. ${ }^{7}$ Before facing strife from Radirobanes, Meleander's realm of Sicily is assailed by the tempest of civil war stirred up by Lycogenes, who is after 'both the sceptre of Meleander and the marriage of Argenis' ('et sceptrum Meleandri et Argenidis nuptias'). ${ }^{8}$ Yet, this does not explain the choice of Sicily as the main location, as opposed to other islands such as Sardinia, which appears as the territory ruled by Radirobanes and which similarly provides a geographical location, between Italy and Africa, convenient for Barclay's plotting. ${ }^{9}$

The critical attention paid to the contribution of the Sicilian setting has focussed on myths attached to Sicily. ${ }^{10}$ In particular, the myth of Persephone's abduction is exploited, as it had been by the one extant ancient novel, Chariton's Chaereas and Callirhoe, which, through its inclusion of Syracuse, provides a precedent for a Sicilian setting. ${ }^{11}$ Contemporary readers would have been familiar with classical myth in many spheres, as seen in the classical mythologizing of landscape gardens, often through the lens of Ovid's Metamorphoses, ${ }^{12}$ or the live application of myths to rulers in political propaganda (so, for example, the way Henry IV is figured as Perseus in a print circulated after his entry into Paris in 1594). ${ }^{13}$ That Sicily could have readily been viewed through the prism of classical myth by contemporaneous readers of

\footnotetext{
${ }^{6}$ For piracy in the ancient novel, see D. Jolowicz, 'Sicily and Roman Republican History in Chariton's Chaereas and Callirhoe', The Journal of Hellenic Studies, 138, 2018, pp. 127-49 (133 n. 53).

7 For storm imagery applied to Lycogenes's conflict, see, e.g. R-H, p. 332 (II.14.2); R-H, p. 352 (II.16.3); R-H, p. 428 (III.1.14), referencing the help of Archombrotus and Radirobanes; R-H, p. 452 (III.4.12); R-H, p. 478 (III.7.5), of Radirobanes's help; cf. also R-H, p. 444 (III.4.3), of future factions.

8 R-H, p. 120 (I.3.8).

9 A journey from Sardinia to Italy could similarly divert to Mauritania following shipwreck and events on a pirate ship: R-H, pp. 292-312 (II.9.1-II.11.1). Admittedly, Sicily does have the advantage of being much closer to Italy. This allows Barclay to exploit the idea of Sicily's quondam separation from the mainland in order to evoke its current state of civil dissension. See the poet's verses at R-H, p. 264 (II.4.5): 'As once when the island, separated from the Italian shore, was terrified at the rain-clouds breaking upon it' ('quondam Ausonio cum dissociata recessit / Litore, frangentes exhorruit insula nimbos'). The idea goes back to the ancient geographers and poets: Barclay may have been inspired by Lucan's repeated use of the motif to suggest Italy's civil strife, for which, see J. Tracy, Lucan's Egyptian Civil War, Cambridge, 2014, pp. 35-6.

10 See Connors 'Metaphor and Politics' (n. 5 above), pp. 251-7, and see below on Ovid's Sicilian myths.

11 Chariton's novel exploits the tale of Persephone's abduction: J. Alvares, 'Utopian Themes in Three Greek Romances', Ancient Narrative, 2, 2002, pp. 1-29 (11-13). One of the key models for the text, Heliodorus's Aethiopica (Bearden Emblematics [n. 4 above], pp. 138-9), uses the settings of Greece, Egypt and Ethiopia.

12 See J. D. Hunt, 'Ovid in the Garden', AA Files, 3, 1983, pp. 3-11.

13 He had freed France (Andromeda); see C. Vivanti, 'Henry IV, the Gallic Hercules', Journal of the Warburg and Courtauld Institutes, 30, 1967, pp. 176-97 (182-3). Cf. R-H 702 (IV.13.12), where Poliarchus, who has freed France by his defeat of Commindorix, is portrayed as Perseus, who freed Andromeda from her chains.
} 
Barclay is suggested by its inclusion as one of the topics of Meleander's discourse to Radirobanes at dinner, alongside natural history and Sicilian history. ${ }^{14}$ Visitors to the island could have knowledge of the well-preserved ancient ruins, such as the temple of Venus Eryx or Castor and Pollux, as could armchair travellers by means of contemporary guides like Fazello's influential De rebus Siculis decades duae, published in 1558. Such familiarity with material culture, in addition to literary accounts of Sicily like those found in Ovid's Metamorphoses, helped build up the island's association with classical myth. While this article will include consideration of myths, its main focus is to explore how the selection of Sicily is driven in part by the interpretative possibilities raised by this location, especially those fuelled by controversies regarding the rational and mythic which were attached to the island. ${ }^{15}$ The first part considers the novel's portrayal of Sicily in light of material associated with the classical tradition, paying especial attention to the final chapter of Book II, ${ }^{16}$ in which Meleander debates gigantic bones, Cyclopes and volcanoes with Radirobanes. "The Interpretative Failures of Radirobanes and Meleander" section below discusses the interpretative failures of Meleander and Radirobanes in the novel. The third section argues for the centrality of the issue of interpretation in the Argenis. In the process, the article contributes to two recent critical debates. The first is whether we may, with Zhang but in opposition to Tang, perceive divine providence in the novel. ${ }^{17}$ The second debate concerns Meleander's characterization. It is clear that the novel displays support for absolute rule, showing that monarchs should be free to exercise their sovereign will. ${ }^{18}$ At the same time, Barclay's ideal absolute ruler is an enlightened one, and the novel is generally held to use the characterization of Meleander to warn against a king's potential flaws, such as credulity or a lack of agency (it is telling that Meleander can only converse so much because he has offloaded care of the war and the camp to Eurymedes). ${ }^{19}$ Should we follow E. L. Christie's argument that Meleander's 'perceived credulity' is 'mere dissimulation,

\footnotetext{
14 R-H, pp. 408, 410 (II.22.6).

15 Space precludes consideration of other potential draws of the location, such as Sicily's association with crimes of jealousy and revenge, for which see G. Bullough, Narrative and Dramatic Sources of Shakespeare, VIII: Romances: Cymbeline, The Winter's Tale, The Tempest, London, 1975, p. 125, in consideration of the setting of Shakespeare's The Winter's Tale.

16 R-H, pp. 400-10 (II.22).

17 See R. D. Zhang, 'A Certain Blindness: Romance, Providence, and Calvin in John Barclay's Argenis', Studies in Philology, 116, 2019, pp. 303-27, and C. Tang, Imagining World Order: Literature and International Law in Early Modern Europe, 1500-1800, Ithaca, 2018, pp. 182-7.

18 See R-H, p. 732 (IV.18.1): Hyanisbe's initial inability to autonomously raise taxes in order to fund more troops is depicted as a threat to Mauritania's safety.

19 R-H, p. 402 (II.22.1). Meleander's culpable passivity is also shown in the way he fails to provide sufficiently strong leadership, which not only facilitates the challenge of the rebellious nobleman Lycogenes but also fosters the kind of conditions in which an internal power struggle can form at the court: R-H, p. 916 (V.16.2) suggests that courtiers reduce their advice following the division between Argenis and her father over the matter of Argenis's future husband; cf. P. Salzman, English Prose Fiction, 1558-1700: A Critical History, Oxford, 1985, pp. 153-4. See, e.g. Tang, Imagining World Order (n. 17 above) p. 182, on the importance of agency in the novel.
} 
adopted because he recognises the value of shows of trust as political manoeuvres' and 'question ... the critical assertion that Meleander is a weak king who must learn prudence over the course of the romance'? ${ }^{20}$

\section{Sicily in the Novel and the Classical Tradition}

Writings from Greco-Roman antiquity would have been key in readers' access to Sicily's myths and natural history, two out of the three areas marked out as of audience interest through Meleander's adoption of them as dinner conversation topics. ${ }^{21}$ For his ideal reader, Barclay conjures a text dotted with verbal allusions to the Metamorphoses. ${ }^{22}$ Note, for example, the poem portraying the king's grove, ${ }^{23}$ which looks to Ovid's depiction of Orpheus's grove at Metamorphoses, X.86-105, ${ }^{24}$ or Nicopompus's verses on the disguised Olympians' escape from Typhoeus, ${ }^{25}$ cited by Arsidas to encourage Poliarchus to adopt a disguise which will aid his flight. ${ }^{26}$ Furthermore, the text often displays an Ovidian-style interest in the metamorphic process using myths drawn from that epic, as we can observe in the description of the Aeacus masque costume, ${ }^{27}$ which recalls metamorphic details from Ovid's depiction of the ants scattered from an oak tree at Metamorphoses, VII.639-42, ${ }^{28}$ or the portrayal of the ring showing the petrification of Atlas. ${ }^{29}$

\footnotetext{
${ }^{20}$ See E. L. Christie, 'Dissimulating Romance. The Ethics of Deception in Seventeenth-Century Prose Romance', DPhil. diss., University of Oxford, 2016, pp. 151-2. For the belief that the excessively trustworthy Meleander is shown learning lessons, see, e.g. A. Hadfield, Literature, Travel, and Colonial Writing in the English Renaissance, 1545-1625, Oxford, 2007, p. 199; D. Invernizzi, 'L'Argenis di John Barclay (1582-1621) e la sua influenza sul Romanzo Italiano Seicento', PhD diss., Università Cattolica del Sacro Cuore, 2017, pp. 73-4, online at: DocTA - Doctoral Theses Archive; ibid., pp. 83-4, for the argument that Argenis learns from her mistakes, like her father.

${ }^{21}$ Etna: R-H, pp. 406, 408 (II.22.4-5); myths: R-H, pp. 408, 410 (II.22.6).

${ }^{22}$ See Connors 'Metaphor and Politics' (n. 5 above), pp. 251-7.

${ }^{23}$ R-H, pp. 500, 502, 504 (III.11.2).

${ }^{24}$ Connors 'Metaphor and Politics' (n. 5 above), p. 255. Cf., e.g. R-H, p. 500 (III.11.2): 'Cupressus / Tollitur in metas' ('the cypress is raised into a conical column') with Ovid, Metamorphoses, X.106: 'metas imitata Cupressus' ('cypress imitating conical columns').

${ }^{25}$ R-H, pp. 168, 170, 172 (I.12.4).

${ }^{26}$ R-H, p. 168 (I.12.3). The bold, ibid., poet Nicopompus like the hubristic Pierid singer, echoes the Pierid's song in his description of disguise; cf. Ovid, Metamorphoses, V.327: "“duxque gregis" dixit "fit Iuppiter"' ("and Jupiter becomes the leader of the herd", she said'), and R-H, p. 170 (1.12.4): 'nullumque timet grex iste Typhoëm?' ('and does that herd fear no Typhoeus?'). See Connors 'Metaphor and Politics' (n. 5 above), p. 254.

${ }^{27}$ R-H, p. 582 (III.23.5).

${ }^{28}$ Cf. ibid.: 'An oak and ants filled the clothing of Aeacus; these now erect with human faces, others had not yet lost their feet' ('Vestem Aeaci quercus implebat atque formicae; hae iam vultibus humanis erectae, aliae nondum crura posuerant') with Ovid, Metamorphoses, VII.639-42: 'they suddenly seemed to grow larger and larger and to raise themselves from the ground and to stand with erect form and to lay aside their leanness, the number of their feet and their black colour and to take on human form with their limbs' ('crescere desubito et maius maiusque videri /ac se tollere humo rectoque adsistere trunco/ et maciem numerumque pedum nigrumque colorem / ponere et humanam membris inducere formam').

${ }^{29}$ Cf. R-H, p. 324 (II.12.3): 'But the appearance of Atlas was of him being indignant that he was being changed; his hair, growing, stiffened into the beginning of woods and on his face a form was gradually extending, as if it were not now yet of a man and not yet a mountain' ('Sed Atlantis habitus erat indignantis se mutari. Rigebant in silvarum primordia comae crescentes et in vultu figura serpebat, qua-
} 
Barclay naturally draws on the Sicilian material of the Metamorphoses. Meleander waits in a palace courtyard containing fountain statuary: ${ }^{30}$ Galatea laments her dead lover Acis, who has been killed by Polyphemus and whose fluminal metamorphosis is captured by fonts pouring from his mouth and wound, and 'at the border of the water, an unyielding statue of the Cyclops ... loomed over unconcerned Galatea with another rock' ('In confinio aquae, contumax Cyclopis imago ... alio saxo imminebat securae Galateae'). ${ }^{31}$ This story is brought up in a way that conjures up Ovid's version in Metamorphoses XIII. ${ }^{32}$ That tale is then one of a number recounted to Radirobanes by Meleander alongside several other Sicilian myths, which, as Catherine Connors observes, 'footnote' Ovid's Sicilian tales. ${ }^{33}$ Thus, the novel follows the Metamorphoses which had included an account, within Book V's 'Musomachia', of how the river-god Alpheus from Elis pursued his would-be lover Arethusa under the sea. ${ }^{34}$ And so the Argenis also references in this section the abduction of Proserpina from Enna, which had also been narrated in Ovid's song contest. ${ }^{35}$ The attempts on Proserpina and Arethusa are of especial resonance to the plot, for both Lycogenes and Radirobanes, who is 'another Lycogenes', try, albeit unsuccessfully, to force Argenis into marriage. ${ }^{36}$ Additionally, Barclay draws on the account in the Metamorphoses of Glaucus and Scylla, which is appended to the story of Acis. In his description of the costumed masqued performers, Barclay

\section{Footnote 29 (continued)}

lis nec iam hominis et nondum montis esset'), with Ovid, Metamorphoses, IV.657-62: 'Atlas became a mountain, as great as he was; for his beard and hair are changed into woods; his shoulders and hands are ridges, what was previously his head is the peak on the top of a mountain, his bones become stones; then he grew, lofty, into a vast thing in all parts (so, you gods, you decreed it) and the whole of the sky with so many stars rested on him' ('quantus erat, mons factus Atlas: nam barba comaeque / in silvas abeunt, iuga sunt umerique manusque, / quod caput ante fuit, summo est in monte cacumen, / ossa lapis fiunt; tum partes altus in omnes / crevit in inmensum ( $\mathrm{sic}$, di, statuistis) et omne / cum tot sideribus caelum requievit in illo').

30 R-H, pp. 152, 154 (I.10.2).

31 R-H, p. 154 (I.10.2).

32 See Connors 'Metaphor and Politics' (n. 5 above), pp. 253-4, on how Galatea's words to the Cyclops who has killed her lover (R-H, p. 154 [I.10.3]) conjure Polyphemus's verses to his unresponsive beloved (Ovid, Metamorphoses, XIII.789-807).

33 R-H, p. 408 (II.22.6). Connors, 'Metaphor and Politics' (n. 5 above), p. 255. In the second reference at R-H, p. 408 (II.22.6), Galatea flees Polyphemus's rock, no longer 'unconcerned' ('securae'): R-H, p. 154 (II.22.6), a foreshadowing of Argenis's escape from Radirobanes.

${ }^{34}$ Cf. Ovid, Metamorphoses, V.577-641, with Argenis, R-H, p. 408 (II.22.6).

35 See Connors, 'Metaphor and Politics' (n. 5 above), pp. 254-7, for the use of the Proserpina myth. As we have seen, the first entry in the contest, the Pierids's theomachic song, is also exploited.

36 The description is Archombrotus's, 'Lycogenem alium': R-H, p. 590 (III.25.1). Radirobanes's attempt will be foiled, unlike that of Dis and Alpheus, though Ovid's presentation of the latter tale has an ambiguous conclusion: P. Murgatroyd, 'Entertaining Arethusa', Museum Helveticum, 69, 2012, pp. 177-89 (188). The failures of Lycogenes and Radirobanes fit their mapping onto unsuccessful rapists: Ixion in the case of Lycogenes: 'burning with the lusts of Ixion, and only embracing the sham of an empty cloud' ('furiisque Ixionis ardens, / Et tantum amplexus vacuae ludibria nubis!'): R-H, p. 122 (III.25.1), and Pirithous in the case of Radirobanes: R-H, p. 590 (III.25.1). As part of his attempt, Radirobanes, who has been encouraged by Selenissa with the advice that 'the gods have also found wives for themselves by abduction' ('ex raptu dii quoque sibi uxores invenerunt'): R-H, pp. 560, 562 (III.21.2), organizes a masque in which he dons the costume of the serial rapist Jupiter: R-H, p. 582 (III.23.6). 
recalls Ovid's description of Glaucus, the fisherman turned sea-god, who enters the Metamorphoses (XIII.904-XIV.69) as he travels past Sicily on his way from Greece to Italy: 'Glaucus had let grow in length such a beard, in which the effective herb near Anthedon surprised him' ('Glaucusque talem barbam promiserat, in quali eum efficax gramen prope Anthedonem deprehendit'). ${ }^{37}$

Ovid's Metamorphoses is not, however, the only Greco-Roman text of relevance, for portrayals of Sicily stretch far back in the classical tradition. Some accounts privilege an interest in Sicily's natural phenomena, others the mythological stories, but what is striking is the awareness of the incompatibility of the mythological and rationalizing perspectives in the context of Etna. There was a long tradition of polemic whereby scientific accounts were pitted against mythological aetiologies for Etna's volcanic action (the idea that Etna covered one of the giants who took part in the rebellion against the gods or served as a forge for Cyclopes). ${ }^{38}$ Lucretius presents a scientific view, arguing that the flames are due to the heating and friction effects of the air in Etna's subterranean caverns, ${ }^{39}$ but he brings up supernatural explanations to put their dismissal in greater relief. Thus, as Monica Gale has noted, the inclusion of anthropomorphic language in the description of Etna at De rerum natura, I.722-5, nods to the tradition that the volcano trapped a giant. ${ }^{40}$ And, at VI.639-702, Lucretius accounts for Etna's eruptions through wind and sea activity but, by including the word 'fornacibus', evokes the myth that this was due to Cyclopes using Etna as a forge. ${ }^{41}$ Virgil's anthropomorphized description of Etna, with its reference to the tale that the volcano lay on Enceladus (Aeneid, III.571-82), pointedly remythologizes Lucretius. ${ }^{42}$ At Metamorphoses, V.346-58, Ovid also counters Lucretius by connecting Etna's volcanic and seismic activity to Typhoeus. ${ }^{43}$ Friction with this viewpoint is then created by the insertion at Metamorphoses, XV.340-55, of a series of scientific causes through the mouthpiece of Pythagoras. ${ }^{44}$ The anonymous first-century AD poet of the Aetna provides rebuttals to mythological explanations. At Aetna, 29, he labels the idea that Aetna's fires are due to the presence of the god Vulcan as a 'fallacy of poets' ('fallacia vatum'), before going on to dismiss the belief that the volcano houses the forges of the Cyclopes and the 'impious tale ('impia fabula', Aetna, 42) that ascribes movement and fire to Enceladus (ibid., 36-40, 41-76). A deliberate tension is then created by the comment that an eruption

\footnotetext{
37 R-H, p. 582 (III.23.5). Cf. Ovid's reference to Glaucus's 'dark green beard' ('viridem ferrugine barbam') at Metamorphoses, XIII.960.

38 Enceladus and Typhoeus are the two most common choices. The presence of furnaces in the volcano provided an alternative explanation; see, e.g. Virgil, Georgics, I.471-3.

${ }^{39}$ Lucretius also considers the contribution of the sea: see De rerum natura, VI.680-93.

40 See M. R. Gale, Myth and Poetry in Lucretius, Cambridge, 1994, p. 87 n. 98.

41 Ibid., p. 187.

42 See P. R. Hardie, Virgil's Aeneid: Cosmos and Imperium, Oxford, 1986, pp. 263-5.

43 See P. Chaudhuri, The War with God: Theomachy in Roman Imperial Poetry, New York, 2014, p. 100.

44 See G. Williams, Pietro Bembo on Etna: The Ascent of a Venetian Humanist, New York, 2017, pp. 54-6.
} 
prompts Jupiter to fear lest the giants are readying for a second gigantomachy (ibid., 203-7): following the reading of Gareth Williams, we may see this as a staging of the threat which the wondrous volcano poses to the rationalizing process. ${ }^{45}$

The tension between mythological and scientific also appears in accounts from the post-classical period. As Williams has explored, the doubleness of perspective in the treatment of Etna continues in Pietro Bembo's De Aetna, which was printed in $1496 .{ }^{46}$ This dialogue between Pietro and his father Bernardo, recounting Pietro's ascension of the volcano, includes a discussion of the subterranean and volcanic activity of Mount Etna (De Aetna, 30-8), with a classically informed rationalization by Bernardo (ibid., 33-8) in response to questions. ${ }^{47}$ Bernardo's comment regarding wind activity within Etna dismisses mythological explanations: 'Yes indeed - unless there's more truth in the fabulous inventions that poets concoct about Typhoeus and Enceladus. ${ }^{48}$ Pietro's wondrous and imaginative stance, whilst similarly committed to a naturalistic account of the volcanic fire, is more sympathetic towards the mythological, as we can see in his allusion to Hesiod describing the earth 'being set on fire after Typhoeus was blasted by a lightning bolt' (ibid., 39, 'post fulminatum Typhoeum igne correptam ... isto') ${ }^{49}$

An appreciation of the dual perspectives associated with Etna can shed light on Barclay's Argenis, for it is clear that he draws on this tradition even though evidence of engagement with these specific passages is lacking. The text features two categories of explanation behind volcanic activity. One account is scientific, seen when Meleander responds to Radirobanes asking 'from where was that help from Aetna against Anaximander' ('unde illud ab Aetna in Anaximandrum auxilium'). ${ }^{50}$ The king relates that the mountain 'seething with native sulphur and wind received in its interior, lifts a flame, impatient of its confinement, through the ruins of its gaping top' ('qui nativo sulphure receptoque in visceribus vento exaestuans impatientem custodiae flammam per hiantis ruinas cacuminis attollit'). ${ }^{51}$ The other kind of explanation is supernatural, based on the idea that deities have control over volcanic activity. So, Nicopompus attributes volcanic activity to the imprisonment of the god-fighting giant Enceladus under 'Etna, that can contain a monster' ('Aetna capax monstri'). ${ }^{52}$ Thus, the existence of stones raining from the sky, which the Sicilian context encourages us to see as a volcanic phenomenon, is considered portentous by the people, and a poet, who describes the 'state of the wretched people' ('miserorum statum' $)^{53}$ worried by these portents, classes volcanic smoke as one of

\footnotetext{
45 Ibid., pp. 67-8. Cf. also the intrusion of mythology at Aetna, 560-1, where Etna's fire is likened to that of Jupiter's thunderbolt.

46 See Williams, Pietro Bembo (n. 44 above), p. 25.

47 Ibid., pp. 19, 223.

48 Pietro Bembo, De Aetna, 31 'Sane quidem, nisi tamen veriora illa sunt, quae de Typhoeo, deque Encelado poetarum fabulositas concinnavit'; text and translation from Williams, Pietro Bembo (n. 44 above), pp. 336-7.

49 See Williams, Pietro Bembo (n. 44 above), p. 256; cf. ibid., p. 267.

50 R-H, p. 406 (II.22.5).

51 R-H, pp. 406, 408 (II.22.5).

52 R-H, p. 122 (I.3.9).

53 R-H, p. 264 (II.4.4).
} 
the divine signs: 'do you see how Aetna raises black coils from its exhaling ridge?' ('Cernis anhelanti quam nigra volumina tollat / Aetna iugo?') ${ }^{54}$ So, too, popular opinion holds that the gods break the siege of Catana through using a volcano. A messenger from the governor brings news that an eruption from Etna into the camp of Anaximander has saved the town: 'Aetna suddenly seething in fury, aside from the huge quantity of stones and heaps of ash, vomited three streams from the very liquid fire which flowed into the camp of Anaximander as though by a hired service' ('Sed cum extrema imminerent, Aetna subito furore exaestuans praeter ingentem vim lapidum et cinerum moles tres ex liquidissima flamma rivos evomuit, qui tanquam conducta opera in Anaximandri castra fluxerunt'). ${ }^{55}$ The narrative depicts joy among Meleander's soldiers at this news as they believed: 'There was now no need of the sword, no need for forces; the gods themselves, the elements themselves were fighting for rulers' ('Non iam ferro, non viribus opus; ipsos deos, ipsa pro regibus elementa pugnare'). ${ }^{56}$ This reasoning goes on to be adopted by Meleander, who tells Radirobanes 'as you hear being announced, the gods made these fires from Etna, which were before our punishments, now their benefaction' ('ut audis nuntiari, dii hos ignes ex Aetna, supplicia antea nostra, nunc beneficium suum fecềre'). ${ }^{57}$

Such supernatural explanations are presented as inferior to the rationalistic account. The idea of Enceladus causing the fires of Etna comes in the context of Nicopompus's musing as to whether Lycogenes shall suffer Enceladus's fate of entombment under the volcano: ${ }^{58}$ rather than being taken at face value, the verses need to be regarded as working to criticize Lycogenes by paralleling him with a giant. We realize that the commonfolk consider the stone-falls ominous because they are being manipulated for political gain. ${ }^{59}$ As we later learn from Meleander, Etna does emit stones along with flames and a thundering noise: 'huge rocks are sent up into the fields from the interior of the mountain with this engine for hurling stones' ('saxa ingentia ex montis visceribus hoc tormento in campos mittuntur'). ${ }^{60}$ The phenomenon is believed to be portentous because of the existence of other signs and omens predicting disaster. These signs, however, have been faked by priests, who have been bribed by Lycogenes in order to prompt action against Meleander, and the commonfolk are said to fear and believe everything 'rashly' ('temere'). ${ }^{61}$ The validity of the idea that volcanic cloud is a portent is undermined by its attribution to a poet who is 'not free from the common madness' ('publicae insaniae non expers'). ${ }^{62}$ The words of Meleander show that, in fact, such clouds 'very often'

\footnotetext{
${ }^{54}$ R-H, p. 264 (II.4.5). See R-H, p. 264 (II.4.4) for the stone-falls (along with twin suns); showers of stones do appear in lists of portents in apparently non-volcanic contexts (e.g. Livy, XXX.38).

55 R-H, p. 406 (II.22.4).

56 Ibid.

57 R-H, p. 408 (II.22.6).

58 R-H, p. 122 (I.3.9).

59 R-H, p. 264 (II.4.4).

60 R-H, p. 408 (II.22.5).

61 R-H, p. 264 (II.4.4).

62 Ibid.
} 
('saepissime') darken the sky around Etna. ${ }^{63}$ The ensuing explanation of subterranean winds and sulphur proffered by Meleander raises questions about the soldiers' belief that gods were involved in the siege. ${ }^{64}$ Admittedly, Meleander then goes on to ignore his scientific account and adhere to the troops' supernatural beliefs. This can be taken, however, as evidence of Barclay's characterization of him as someone liable to misinterpret, freely swayed and too prone to accept an easy and palatable explanation. Damningly, his acceptance of the supernatural explanation leads him to a perilous state of reassurance, heedless of the danger still posed by Lycogenes (who that very night raises an attack against the camp ${ }^{65}$ or the threat that Radirobanes represents.

Of course, Barclay's undercutting of the supernatural explanations does not mean they cannot contain a poetic truth of sorts. The idea that Etna's volcanic activity is due to an imprisoned giant equates Lycogenes's rebellion with war against deities. ${ }^{66}$ The motif is picked up in Nicopompus's parallelism of the revolt with the attack of Typhoeus (a model for Lycogenes) against the gods, ${ }^{67}$ and then again where Mars's distaste for the fighting between Lycogenes and Meleander is likened to his distaste at the time when gods hid during a gigantomachy ${ }^{68}$ In line with Barclay's belief in absolute rule, a monarch is god's lieutenant on earth. ${ }^{69}$ And those who rise against a king are figured through gigantomachic myth as rebels against the divine. ${ }^{70}$ Through the figuration of Lycogenes as a second Enceladus, the noble's impious stance against the divinely ordained ruler is adumbrated, and his defeat is prefigured. Nicopompus, who can act as an authorial figure, deploys myth to adumbrate a kind of truth consonant with Barclay's approach. ${ }^{71}$ Furthermore, on one level we may view volcanic activity as foreshadowing the trouble caused by Lycogenes and the threat

\footnotetext{
63 R-H, p. 408 (II.22.5)

64 R-H, pp. 406, 408 (II.22.5).

65 See the uproar at R-H, p. 410 (II.22.6), which turns out to be Lycogenes's attack: R-H, pp. 416-23 (III.I.2-12).

66 R-H, p. 122 (I.3.9).

67 R-H, pp. 168, 170, 172 (I.12.4). Barclay conflates monstrous attacks against the Olympians, as the fights of giants, Titans, Aloidae and Typhoeus were commonly conflated in antiquity: see Hardie, Virgil's Aeneid (n. 42 above), p. 85. See the reference to the piled-up mountains lifting Typhoeus towards the sky, R-H, p. 168 (I.12.4) and cf. R-H 120, 122 (I.3.9). Note, too, that at R-H, pp. 168, 170 (I.12.4), Barclay draws on the gigantomachic simile at Statius, Achilleid, I.484-90: there is similar stress on pallor, albeit of the gods (I.484) instead of stars, the weaponry of Mars (I.485) and gorgon of Pallas's aegis (I.486).

68 R-H, p. 426 (III.1.14).

69 Cf. R-H, pp. 534, 536 (III.16.3): 'the name [of king] nearest to the gods' ('proximum diis nomen').

70 So, at R-H, p. 702 (IV.13.12) a druid's verses characterize Commindorix, a Lycogenes figure who challenges Britomandes's rule (R-H, p. 688 [IV.12.1]), as a 'savage giant' ('Saevum ... Giganta'). Prior to this, the druid pictures Commindorix killed by deities who are depicted in such a way as to evoke their participation in the gigantomachy; see Invernizzi, 'L'Argenis' (n. 20 above), p. 77. For gigantomachic allusions in the Argenis, see Connors 'Metaphor and Politics' (n. 5 above), p. 252; Invernizzi, pp. 72, 75-7; F. G. Mohamed, Sovereignty: Seventeenth-Century England and the Making of the Modern Political Imaginary, Oxford, 2020, p. 68 (linking Anaximander's rebellion with the consequent eruption of Aetna on him and his troops, and seeing justice in the idea of Jupiter striking down the giant-figure).

71 For Nicopompus as the mouthpiece for Barclay, see below.
} 
posed by the rebels against the king. Just as Lycogenes poses a threat to political stability, so Etna's activity is a threat to the island's physical stability. ${ }^{72}$

We may again see the clash of views regarding myth and scientific approaches to natural history in the case of giant bones. In Barclay's own day, there were investigations into the question of the origins of enormous bones which were being discovered. Were they evidence of superhuman creatures like giants or, as Fazello and others like him thought, Cyclopes? ${ }^{73}$ Or were they the remnants of animals? Barclay's friend and correspondent Peiresc identified remains as being from non-mythological creatures such as elephants. ${ }^{74}$ In awareness of this current interpretative controversy, Barclay incorporates such material in his text. ${ }^{75}$ When Meleander returns to camp with Radirobanes, the priests present him with an 'augury' ('omen') which had greatly pleased them, the discovery of giant bones. ${ }^{76}$ These are apparently of a human body (the text inserts a note of scepticism: 'as it seemed' ['ut videbatur']) 'but far surpassing the customary measurement of men of that age' ('ceterum longe assuetam hominum illius saeculi mensuram vincentia') ${ }^{77}$ Again, the scientific explanation is presented as superior. The soothsayers make no doubt that these are the remains of one of the Cyclopes. ${ }^{78}$ The text makes clear both the adulatory agenda of the priests, 'the fawning of the congratulating priests showed them the pieces of huge bodies' ('haec illis immensorum corporum frustra gratantium vatum adulatio ostendit') ${ }^{79}$ and the way such flattery can instil a misleading sense of confidence. We are told, 'Without delay the augurs interpreted: that all the strength of Sicily was being subjected to Meleander since nothing in that country was named as stronger than the Cyclopes who, placed under the tent of the king, were indeed surrendering themselves' ('Continuo augures interpretati sunt: omnes Siciliae vires subici Meleandro, cum nihil in ea fuisse validius Cyclopibus memoretur, qui tabernaculo regis subiecti se ipsos denique tradebant' $).{ }^{80}$ Such prediction of success fails to predict the troubles that will beset Sicily before their apparent resolution at the end of the novel. Meleander's gullibility is highlighted by his readiness to believe. ${ }^{81}$

\footnotetext{
72 See R-H, p. 408 (II.22.5), where the people fear the volcano might erupt and overwhelm Sicily.

73 For the belief of Fazello and others that gigantic bones in Sicily proved that Homer's Cyclopes had occupied the island, see G. Godard, 'The Fossil Proboscideans of Utica (Tunisia), a Key to the Giant Controversy, from Saint Augustine (424) to Peiresc (1632)', Geological Society Special Publication, 310, 2009, pp. 67-76 (71); M. Romano and M. Avanzini, 'The Skeletons of Cyclops and Lestrigons: Misinterpretation of Quaternary Vertebrates as Remains of the Mythological Giants', Historical Biology. An International Journal of Paleobiology, 31, 2019, pp. 117-39 (126).

74 See Godard, 'Fossil Proboscideans' (n. 73 above).

75 Contemporary interest is noted at R-H, p. 403 n. 1; Connors 'Metaphor and Politics' (n. 5 above), p. 253 n. 18.

76 R-H, pp. 400, 402 (II.22.1).

77 R-H, p. 400 (II.22.1).

78 R-H, p. 402 (II.22.1).

79 Ibid.

80 Ibid.

81 See his later, proud reference to the discovery of the bones on the site of his tent which seemed 'a most auspicious omen', 'laetissimum monstrum', to the priests: R-H, p. 406 (II.22.3); there may be authorial play with the dual meaning on 'monstrum' as 'monster' and 'omen'.
} 
The king continues to show poor interpretative skills as he discusses the Cyclopes with his interested listener Radirobanes. Meleander announces that 'Some think that the whole race of Cyclops were wild and lived in woods, others think that they were not only worshippers of the gods but also their descendants; they think they were the first to have possessed these habitations and to have been engaged among themselves with simple laws' ('Cyclopum omne genus quidam ferum fuisse et silvestre, alii non deorum modo cultores sed et sanguinem putant; primos tenuisse has sedes; simplicibus legibus inter se agitavisse'). ${ }^{82}$ It is clear that Meleander thinks well of the race, for he explains his belief that negative opinions of the Cyclopes have been due to their huge size: 'And on this account perhaps came the strangers' mistake, that when they landed here, they believed impious minds lay in the huge bodies or, not daring conversation in their terror at the sight, they left the shore using all their rowers' ('Et hinc exteris forte error, ut cum isthuc appellerent, in immanibus corporibus impias mentes latere crederent, aut nec colloquium ausi in ipso terrore spectaculi toto remigio abirent a litore'). ${ }^{83}$ Now there was a tradition whereby certain elements of the Cyclopes's life could be seen positively. The Homeric Cyclopes, lawless and arrogant as they are, live in Hypereia, later identified with Sicily, which, we are told at Odyssey IX.108-11, is a quasi-Golden Age land of abundance requiring no labour. In Homer's Odyssey, IX.108-11, the Cyclopes, lawless and arrogant as they are, live in Hypereia, later identified with Sicily, which is a quasi-Golden Age land of abundance requiring no labour. In Ovid, Metamorphoses, XIV.2-3, the uncultivated lands of the Cyclops who do not know about agriculture form one of the markers of Sicily which is swum past by Glaucus. Furthermore, Polyphemus could be taken as an atypical example of a Cyclops: Homer, after all, shows him living apart from the other Cyclopes (Iliad, IX.187-9). Nevertheless, it is striking that Meleander makes no mental connection here with the example of a Cyclops which should have been familiar to him from the statue in his palace courtyard: the monstrous, violent Polyphemus. The reader is nudged towards perceiving his inconsistency and credulity. Meleander goes on to tell Radirobanes, who had previously held report of Cyclopes as fables, ${ }^{84}$ about similar discoveries. ${ }^{85}$ Meleander manages to convince his fellow ruler, whose credulity is thus likewise underlined. The ideal educated reader whom Barclay would have had in mind would surely have been as sceptical as Peiresc that these were the remains of gigantic creatures.

\footnotetext{
${ }^{82}$ R-H, p. 402 (II.22.2). For the belief that they were Sicily's first inhabitants, see, e.g. Thucydides, VI.2.1. For links between the Cyclopes and the gods, see Homer, Odyssey, VII.205-6; IX.519.

${ }^{83}$ R-H, p. 402 (II.22.2).

${ }^{84}$ R-H, p. 402 (II.22.1).

${ }^{85}$ It seems highly probable that at II.22.3 (R-H 406) Barclay is drawing on Fazello's depiction of a discovery in 1548 in the same location; see A. C. Collignon, Notes historiques, littéraires et bibliographiques sur L'Argenis de Jean Barclay, Paris, 1902, p. 89. See Romano and Avanzini 'The Skeletons' (n. 73 above), p. 127, for this and similar stories. Details in common include the dissolution of the corpse except for part of the head, ribs and shins (II.22.3, R-H 406: cf. T. Fazello, Della storia di Sicilia. Deche due: tradotte in lingua toscana, I, Palermo, 1830 (translation of his 1558, De rebus Siculis decades duae), p. 90 (I.VI).
} 


\section{The Interpretative Failures of Radirobanes and Meleander}

The interpretative incompetence of Meleander and Radirobanes, as revealed by the camp episode, is displayed elsewhere in the novel. The novel, indeed, regularly shows characters failing to interpret, often with detrimental effect. These characters can be common people, as demonstrated by the way Poliarchus's arrival in Mauritania sparks harmful misguided speculation and rumour. ${ }^{86}$ Notably, the abuse of portents and omens can lead to misunderstanding among these folk: see, for instance, Cleobulus's advice to buy off the astrologer in awareness that, if angered, he could feign that the stars were baleful, and then 'the soldiers would, not reluctantly, be distressed by his superstitions' ('non aegre superstitionibus militem laboraturum'), ${ }^{87}$ evidence of Barclay's use of 'belief in the supernatural to demarcate the credulous from the rightly sceptical'. ${ }^{88}$ Yet, in line with the novel's interest in the workings of absolute monarchy, deficient interpretation is especially explored in relation to those in power, where consequences can be serious. Hieroleander relates the final verses of an anonymous poet which draw a parallel between Radirobanes and Castor: 'if you mount the back of your steed, Cyllarus, spurning his constellation, will desire your commands and to go to and fro more proudly in the fields of Sardinia' ('Si terga subibis / Quadrupedis, cupiet spreto tua Cyllarus astro / Imperia et Sardis volitare superbior agris'). ${ }^{89}$ Radirobanes is understandably pleased with the analogy: we learn that 'he praised' ('laudabat') the verses 'among his own men' ('apud suos'). ${ }^{90}$ And, in light of his successful ride on horseback through a lake, ${ }^{91}$ this mythic figure could be seen as a good match for him, since Castor was famed for his horse Cyllarus and riding-skills. ${ }^{92}$ However, Radirobanes, who is characterized by Dunalbius as having 'proud credulity' ('superba credulitate'), ${ }^{93}$ is unable to see that the poet is fawning upon him. Hieroleander comments that Radirobanes was 'puffed up with flattery' ('adulatione elatus'), ${ }^{94}$ alerting the reader to the discrepancy with reality. $\mathrm{He}$ is not a true Castor figure, lacking that character's immortality, for, although Meleander had counted Radirobanes 'among the divine guardians of Sicily' ('inter

\footnotetext{
86 See Salzman, English Prose Fiction (n. 19 above), p. 153. See R. A. Schneider, Dignified Retreat: Writers and Intellectuals in the Age of Richelieu, Oxford, 2019, p. 331, for Barclay's critical attitude towards the lower classes.

87 R-H, p. 372 (II.18.1).

88 The quotation is from Christie, 'Dissimulating Romance' (n. 20 above), p. 155. Cf. R-H, p. 438 (III.3.2), to the scorn of the sensible, priests repeat omens suggesting Lycogenes's death had been foreseen.

89 R-H, p. 518 (III.14.2). Castor commonly appears as in panegyrical verse as a figure for comparison, as we can see from Horace, Odes I.12.25-32 (with reference to calming a sea-storm at I.12.29-32). This detail is perhaps in response to the decoration of Radirobanes's flagship with Helen, Castor and Pollux: R-H, p. 387 (II.20.6).

90 R-H, p. 518 (III.14.1).

91 R-H, p. 758, 760 (IV.19.12-13).

92 See, e.g. R-H, p. 798 (V.1.12).

93 R-H, p. 522 (III.14.6).

94 R-H, p. 518 (III.14.1)
} 
caelestes Siciliae tutelas'), ${ }^{95}$ after he had helped him against Lycogenes in the storm of civil war, he dies after being defeated by Poliarchus. Nicopompus envisages Radirobanes in the underworld recognizing the folly of his lack of self-awareness: 'I was a very god to myself' ('Deus ipse mihi') and his poor choice of followers: 'nor were my attendants trustworthy and approval for each thing was worthless' ('Nec fidi comites, vilisque ad singula plausus'). ${ }^{96}$

It is the characterization of Meleander which best shows Barclay's interest in exploring the perils of an undiscerning ruler. Meleander's assertion that Theocrine - who came with a letter of recommendation and elaborate backstory ${ }^{97}$ - is the goddess Pallas highlights his poor interpretative skills. ${ }^{98}$ Failing to get the etymological clue in the name ('to judge a god'), he does not delve into the mystery and thereby remains ignorant of his daughter's relationship with Poliarchus, which poses a potential threat to Sicily's stability. ${ }^{99}$ We are also shown Meleander's failures of discernment in his credulity. This credulity leaves him susceptible to flattery which has potentially dangerous effects as we may see in the victory procession following Lycogenes's defeat. When Meleander comes to the city gate, there is an image of Peace, ${ }^{100}$ accompanied by verses lauding the arrival of concord in Sicily. ${ }^{101}$ As the narratorial comment suggests, this is done in 'premature flattery' ('adulatione immatura'), ${ }^{102}$ 'as if matters were pacified in the whole of Sicily' ('quasi pacatae res Sicilia tota essent'). ${ }^{103}$ This encourages a dangerous state of over-confidence in light of the threat posed by Radirobanes.

Credulity is a character flaw which is a vice for a king. A ruler must not place trust where it is not warranted: indeed, he must be careful to evaluate others. The naïve Meleander's failure to gauge character goes hand in hand with his excessive trustworthiness. We initially encounter the king through the background explanations of Poliarchus which include comments on his interpretative failings, such as: 'he chose friendships with no plan and cultivated them with passion' ('non consilio amicitias sortiri impetuque eas colere'). ${ }^{104}$ Poliarchus notes Meleander has been

\footnotetext{
95 R-H, p. 432 (III.2.2).

96 R-H, p. 794 (V.1.12).

97 R-H 484-90 (III.8.3-11).

98 R-H, p. 542 (III.18.2).

99 For the etymology, see S. Siegl-Mocavini, John Barclays "Argenis" und ihr staatstheoretischer Kontext: Untersuchungen zum politischen Denken der Frühen Neuzeit (Frühe Neuzeit, 48), Tübingen, 1999, p. 310 .

100 R-H, p. 438 (III.3.2).

101 R-H, p. 438 (III.3.3).

102 R-H, p. 438 (III.3.2).

103 Ibid. For another example of the fawning which surrounds the king, see the attribution of 'flattery' ('adulatione'), at R-H, p. 544 (III.18.3) as one suggested reason for a soldier's attribution of ascending light to Pallas, following Meleander's claim that Theocrine was Pallas. At R-H 204 (I.18.1), the dangers of flattery are voiced by Anixamander, whose dissatisfaction with Meleander's rule causes him to rebel, and Hyanisbe at R-H, p. 940 (5.19.6e); see H. Moore, 'Romance: Amadis De Gaule and John Barclay's Argenis', in The Oxford Handbook of English Prose 1500-1640 ed. A. Hadfield, Oxford, 2013, pp. 59-76 (73); Christie 'Dissimulating Romance' (n. 20 above), p. 149.

104 R-H, p. 110 (I.2.3). Cf. ibid.: 'since the times and ways of men are not assessed' ('qui non saeculo, non hominum moribus aestimatis').
} 
deceived by the nobleman Lycogenes, whom he believed was his friend, ${ }^{105}$ with the consequence that civil unrest has come to Sicily. ${ }^{106}$ Poliarchus later goes on to claim that the king is: 'exposed to plots, both by the corrupted characters of his own men and by the greatness of his own spirit, shunning just fears' ("patere ... insidiis, tum corruptis suorum ingeniis, tum sui animi magnitudine iustos metus aversante'). ${ }^{107}$ We should not unthinkingly take Poliarchus's observations at face value but make our own assessment as we proceed through the text. Poliarchus's comments arguably underplay the severity of the problem given the threats to Sicily which are revealed by the narrative, and we may well wonder whether the later musing on the difficulty of critiquing rulers should prompt us to retrospectively suspect excessive leniency here. ${ }^{108}$ It is surely not the case, however, that Poliarchus's words are necessarily invalidated by any later instances in which his judgement might itself be in question, as Christie avers. ${ }^{109}$ The situation is not black and white. The narrative does show the king displaying credulous behaviour, as we can see from his assumption about Theocrine. Yet, it also reveals his shrewdness: for example, Meleander fakes guidance from the gods, such as through stars and oracles, to conceal his true reason for hiding Argenis away in a castle. ${ }^{110} \mathrm{He}$ can both be misled in the area of the divine and manipulate supernatural events. The reader is sucked into the interpretative challenge of judging his character and deeds.

\section{Interpretation in the Argenis}

We have seen how interpretation comes up as an issue of characterization. We have also seen that readers become involved in interpretative challenges in their assessment of protagonists. The Argenis, in fact, brings to the fore the interpretative process and the inherent need for interpretation, even though there are instances of narrative ambiguity and moments when interpretative certainty is withheld. ${ }^{111}$ This pertains at the level of structure and plot, for, from the moment he is plunged into the novel in medias res, the reader is forced to piece together and to track the twists and

\footnotetext{
105 Ibid.

106 Meleander's faults of credulity and lack of agency may combine: in the words of Poliarchus, at R-H, p. 110 (I.2.3), 'he often consigned' business 'to the untrusty' ('plerumque infidis credebat'). Some of the men he selects to serve him, like Lycogenes, are poorly chosen. Meleander's aversion to business had allowed Lycogenes to fill the court with his own men and strengthen his position: R-H, p. 112 (I.2.3); see Hadfield, Literature (n. 20 above), p. 198.

107 R-H, p. 120 (I.3.8).

108 R-H, p. 444 (III.4.2). The context is Meleander's request for Cleobulus's opinion; see Moore 'Romance' (n. 103 above), p. 72. Cf. Schneider, Dignified Retreat (n. 86 above), p. 329, on R-H, p. 110 (1.2.3), Poliarchus's wish that he could be silent.

109 Christie, 'Dissimulating Romance' (n. 20 above), p. 150.

110 R-H, p. 480 (III.7.6).

111 See Salzman, English Prose Fiction (n. 19 above), pp. 152-3, on the presence of alternative explanations in the narrative. See C. Jowitt, The Culture of Piracy 1580-1630: English Literature and Seaborne Crime, Burlington VT, 2010, on the withholding of interpretative certainty in the presentation of piracy.
} 
turns of the plot. ${ }^{112}$ What, we ask, was the help provided by Pallas, which Poliarchus notes Meleander linked to the foiling of Lycogenes's attack against himself and his daughter? ${ }^{113}$ What does it mean when Poliarchus addresses Argenis by referring to himself as 'your Pallas' ('Palladem tuam')? ${ }^{114}$ When Selenissa relates Poliarchus's confession to Radirobanes, ${ }^{115}$ we hear how Poliarchus disguised himself as a maiden of royal descent, Theocrine, ${ }^{116}$ which informs us that she was understood by Meleander to be a manifest deity, Pallas. ${ }^{117}$

Interpretation is also at the fore in respect of content and themes. Disguise is prevalent in the Argenis at the internal and external level: characters can hide their emotional state and intent - thus Argenis conceals her hope to marry Poliarchus - disguise their names, social class and country (Poliarchus is actually Astioristes, the king of France, who had in the past borne the alias Scordanes), and adopt physical concealment - for example, in his flight Poliarchus uses 'rustic dress' ('rustico habitu') and the fake beards, 'disguises' ('larvas'), ${ }^{118}$ which had belonged to a notorious thief. This content feeds into the novel's concern with interpretation. Internal characters are often misled or mistaken about identities: note, for example, the man captured in the belief that he was Poliarchus who is revealed to be the madman Heraleon. ${ }^{119}$ For the reader, the issue of identity can be bound up with the interpretative process. The reader is privy early on to Poliarchus's adoption of rustic clothing but does not unstrip the layers of his true identity and adopted aliases until further on in the story. ${ }^{120}$

Concurrently, readers become drawn into interpreting at the ethical level: they are encouraged to see parallels with their own behaviour and draw general morals. Barclay uses his novel to point out vices and virtues for the purposes of self-awareness and instructive self-criticism, in the manner which his mouthpiece Nicopompus

\footnotetext{
112 See Zhang, 'A Certain Blindness' (n. 17 above), pp. 315-16.

113 R-H, p. 112 (I.2.4).

114 R-H, p. 231 (1.20.10).

115 R-H, p. 538 (III.17.1).

116 R-H, p. 542 (III.18.2).

117 Cf. R-H, p. 606 (IV.2.5): Argenis telling Meleander); R-H, p. 934 (V.19.2): Poliarchus's recapitulation. Poliarchus had managed, by various means, including a letter allegedly from his mother Alcaea ( R-H, p. 484 III.8.4), to live in proximity to the king's daughter Argenis and this is the origin story for the love between Argenis and Poliarchus: Zhang, 'A Certain Blindness (n. 17 above), p. 311. There are clear resonances with the myth (as told in Statius's Achilleid: cf. 'fraus' at Achilleid, I.28-4; I.364; I.719-20), wherein Achilles's mother Thetis disguised her son as her daughter and hid him among the daughters of Lycomedes at Scyros (except that Poliarchus, although attracted to Argenis like Achilles was attracted to Deidamia, defends Argenis against the attack of Lycogenes, rather than acting like Achilles by raping her himself). The listening Radirobanes perceives something of the mythic parallelism: 'What Achilles therefore is this beneath degenerate robe? Or what Thetis had embellished the deception' ('Quis hic ergo sub palla degeneri Achilles? Aut quae Thetis fraudem ornaverat?': R-H, p. 538 (III.17.2). He does, however, fail to realize how the paradigm renders futile his own marriage prospects: Poliarchus will marry Argenis later, as Achilles does Deidamia.

118 R-H, p. 166 (I.12.1).

119 R-H, pp. 196, 198 (I.17.1-3).

120 Archombrotus is Hyempsal, the heir of Mauritania (as well as being, unbeknownst to himself, the son of the king Meleander). See Zhang, A Certain Blindness' (n. 17 above), p. 316, for how Arsidas's recognition that Ariostides and Poliarchus are the same parallels that of the reader.
} 
proposes for his 'grand fiction in manner of a history' ('Grandem fabulam historiae instar' ): ${ }^{121}$ 'I shall portray vices and virtues and the rewards shall be suited to each' ('Vitia effingam virtutesque et praemia utrisque convenient'). ${ }^{122}$ Readers also get caught up into perceiving parallels with matters of politics and contemporary affairs. ${ }^{123}$ Barclay's engagement with current situations was such that 'keys' to the work swiftly followed the novel's publication: the 1627 Latin edition was accompanied by a 'clavis' which set out political parallels, such as a parallelism between Poliarchus and 'those against whom the frenzy of the Guise and sacred League vented its rage; such as Henry IV, king of Navarre, and the Duke of Epernon'. ${ }^{124}$ The political correspondences may not be simple and the process of ethical evaluation is not necessarily straightforward. ${ }^{125}$ Nevertheless, there is demonstrable interest in the issue of interpretation.

The mythical allusions which run through the novel also bring up the issue of interpretation as readers and internal characters can assess how protagonists are like, or unlike, mythic figures. Note, for example, the verses underneath the tablet dedicated by Timoclea in the temple of Venus Eryx after Poliarchus's escape, which we may assume are at least authorized, if not composed, by Timoclea. They include a comparison between Castor and Pollux and Poliarchus and Archombrotus: 'Nor ever with such a great star have the Oebalian gods shone, whom the sailor invokes when his ship has broken up and the waves are now, now overcoming him' ('Non umquam sidere tanto / Oebalii micuêre dei, quos nauta solutis / Puppibus et iam iam vincentibus invocat undis'). ${ }^{126}$ In part, this comparison affirms an affinity in appearance

\footnotetext{
121 R-H, p. 336 (II.14.5).

122 Ibid. See, e.g. P. Salzman, 'Narrative Contexts for Bacon's New Atlantis', in Francis Bacon's New Atlantis: New Interdisciplinary Essays, ed. B. Price, Manchester, 2002, pp. 28-47 (41): 'Argenis exemplifies these precepts of Nicopompus, containing, as it does, an account of European events and an analysis of significant individuals fictionalised in such a way that general moral doctrines may be discerned by the reader.'

123 For all its romance framework, the novel's concern with politics and statescraft has been evident to contemporary and modern readers alike. For modern scholarship on the politics see, e.g. P. Salzman, Literary Culture in Jacobean England: Reading 1621, Basingstoke, 2002, pp. 76-81; Moore 'Romance' (n. 103 above); Schneider, Dignified Retreat (n. 86 above), pp. 325-36.

124 R-H, p. 47: 'in quos Guisianorum ac Ligae sacrae rabies desaeviit; quales Henricus IV, Rex Navarre et Espernonii Dux'. It was translated for inclusion in the 1636 second edition of Long's translation. See ibid., pp. 45-8, for the key in the 1627 Elzevier edition.

125 See the words of Nicopompus at II.14.5, R-H 336 'the image of no-one will appear simply' ('neminis imago simpliciter exstabit'). See also 2.14.4, R-H 336 (Nicopompus's reworking of Lucretius's honey image from De rerum natura, I.933-50 and IV.8-25, in which he claims that, in order to be palatable, lessons need honey-coating and disguising, just like medicines for sick children) and R-H, p. 336 (II.14.5), noting that 'wholesome herbs', 'salubres herbas', need to be slipped in after the love potion. On the issue of historical correspondence, see Moore, 'Romance' (n. 103 above), pp. 68-70; A. Patterson, Censorship and Interpretation: The Conditions of Writing and Reading in Early Modern England, Madison WI, 1984,
}

p. 182 (on the 'tantalizing because inexact fit' between fact and fiction).

126 R-H, p. 106 (I.1.6). 
between the youthful-looking Disocuri twins and the young men, Poliarchus and Archombrotus, whose physical similarity has been observed by the narrative. ${ }^{127}$

The interpretative process involved in mythic assessment is flagged up through an internal character in the novel's first ecphrasis which concerns fountain statuary. ${ }^{128}$ Attention is paid to Argenis's focalization of the scene: her identification of herself as Galatea and Poliarchus as a 'better Acis' ('meliorem Acim') ${ }^{129}$ and her resulting uncertainty over whom to cast in the Cyclops's role: 'But who should be that Polyphemus? Although she meant Lycogenes by it, yet she also, unwillingly, remembered her father's fault' ('Sed quis ille Polyphemus? Quamquam eo destinabat Lycogenem, tamen et culpae paternae invita meminerat'). ${ }^{130}$ Here Argenis's parallelism is flawed. As reinforced by the echo here of Aeneas's reaction at Aeneid, 1.464, when he over-optimistically reads the scenes adorning Juno's temple which show Trojan defeat, Argenis is actually mistaken: Poliarchus has not, in fact, been killed but faked his death. ${ }^{131}$ Engagement with Apuleius's statue scene of Diana and Actaeon, which is internally focalized through Lucius, also suggests erroneous perception, for Argenis takes the role of the flawed interpreter Lucius. ${ }^{132}$ The reader uses his interpretative skills to detect the error.

Mythic parallelism also opens up proleptic connections which become part of the reader's interpretative journey as they progress through the text. Picking up on the mythological tradition that Castor and Pollux took turns to populate the underworld and the heavens, Bearden suggests that one purpose of the comparison at I.1.6 is to anticipate immediately 'Poliarchus's concealment in a tomb-like underground vault in the very next chapter ... (while Poliarchus is down, Archombrotus is up) ${ }^{133}$ and that another function is to foreshadow the future plot in which the two will - after a rivalry hinted at in the text - become brothers-in-law. ${ }^{134}$ We might add further ways in which the analogy provides connections to future plot lines. The mythic parallelism surely also looks forward to Poliarchus' restoration to health from being seemingly on his death bed which is akin to the way Castor regularly moves from

\footnotetext{
127 See R-H, p. 106 (I.1.5). Cf. R-H, p. 318 (II.11.6) where Hyanisbe sees the young and handsome Poliarchus and is reminded of her son, Archombrotus: R-H, p. 390 (II.20.7).

128 R-H, pp. 152, 154 (I.10.2-4). See Connors 'Metaphor and Politics' (n. 5 above), p. 254; Bearden Emblematics (n. 4 above), pp. 141-2, J. Glomski, 'Politics and Passion: Fact and fiction in Barclay's Argenis', in Seventeenth-Century Fiction: Text and Transmission ed. J. Glomski and I. Moreau, Oxford, 2016, pp. 49-63 (62).

129 R-H, p. 154 (1.10.4).

130 Ibid.

131 Cf. ibid.: 'solitario dolore se pascebat' ('she fed herself with solitary grief') with Virgil, Aeneid, I.464 (in the context of the Aeneid's first ecphrasis) 'animum pictura pascit inani' ('he fed his soul with the empty picture'). For Aeneas's subjective response, see S. Bartsch, 'Ars and the Man: The Politics of Art in Virgil's Aeneid', Classical Philology, 93, 1998, pp. 322-42 (337).

132 See Apuleius, Metamorphoses, II.4 (containing the novel's first ecphrasis). For Lucius's poor interpretation, see, e.g. the way Lucius, who is 'constantly threatened with an Actaeonic rending by dogs, wild beasts, and humans' (J. Heath, Actaeon: The Unmannerly Intruder, New York, 1992, p. 110), does not heed the warnings of the Actaeon spectacle.

133 Bearden, Emblematics (n. 4 above), p. 146.

134 Ibid.
} 
the underworld, as Nicopompus's celebratory verses relate. ${ }^{135}$ Indeed, Castor is surely included in Nicopompus's poem to evoke this parallel (the ghosts mistake him for Poliarchus after Radirobanes's story that Poliarchus was dying). ${ }^{136}$ Furthermore, Castor and Pollux were the deities invoked by distressed sailors, as they were thought to be able to provide calm waters. ${ }^{137}$ They were associated with the electrical discharge, known as St Elmo's fire, which could be found on masts and riggings in storms and which was believed to indicate the Dioscuri's protection. ${ }^{138}$ Since the Dioscuri are recalled in a storm context, ${ }^{139}$ 'sidere' must not merely evoke the gods' 'star', but also look to the light of St Elmo's fire. ${ }^{140}$ The reference foreshadows the help that Archombrotus will later provide to the realm of King Meleander which is beset by metaphorical storms, as well as reflecting the help that Poliarchus has provided by this point in the struggle with Lycogenes. ${ }^{141}$

The novel also shows an interest in interpretation in terms of the politicking of its characters. Those close to the centre of power display eagerness to find out what is going on, for they must gauge how to best play along. These figures must, for example, interpret people and power dynamics so that they can work out how to best please: for example, Anixamander puts forward an anti-monarchic stance in an effort to please his powerful uncle Lycogenes, ${ }^{142}$ although he - in a dialogic move characteristic of the novel - is presented as arguing for the benefits of an elected monarchy. ${ }^{143}$ As well as showing characters trying to read others for political gain, the novel features powerful protagonists attempting to hide their real self or their reaction from external perception. Thus, for instance, Meleander hides his response to the news of Poliarchus's death. ${ }^{144}$ And so, rebels are said to be won over by Lycogenes's 'dissimulation' ('dissimulatione'), ${ }^{145}$ for, 'in the manner of tyrants' ('de more tyrannorum'), Lycogenes presents himself as 'checking vices'

\footnotetext{
135 See R-H, p. 796 (V.1.12): 'But see returning through the darkness of the gloomy world, Castor is here; Then by chance, after having left the post of the sky, he was changing turns with his brother' ('Ecce autem caeci rediens per nubila mundi / Castor adest. Tunc forte poli statione relicta / Mutabat cum fratre vices'). For the alternation between the upper and underworlds, see Virgil, Aeneid, VI.121-2.

136 R-H, p. 796 (V.I.12). For the ghosts' error, see ibid.

137 See the verses on Meleander's boat, wishing for the presence of Castor, Pollus and Helen, at R-H, p. 384 (II.20.2): 'With you be the Oebalian brothers, two stars, and their sister' ('Tecum Oebalii duo sidera fratres, / Et soror').

138 Witness Nicopompus's portrayal of Castor in his celebration of Poliarchus's recovery in the Soteria, at R-H, p. 798 (V.1.12): 'Castor laughed with all his star as if he were driving clouds from the angry sea and descending upon the happy ships with his gleam' ('sidere toto / Risit, ut irato si pelleret aequore Castor / Nubila, et in laetas descenderet igne carinas').

139 R-H, p. 106 (I.1.6).

140 Oxford Latin Dictionary, s.v. 'sidus', 4.

141 Cf. Statius, Silvae, III.2.8-10 'Bring forth your kindly stars, brothers who are born of Oebalus, and sit upon the yard-arm's twin horns' ('proferte benigna / sidera et antemnae gemino considite cornu,/ Oebalii fratres'). For Poliarchus's aid, see, e.g. R-H, p. 518 (III.13.5).

142 R-H, p. 204 (I.18.1).

143 R-H, p. 208 (I.18.6). See Salzman, English Prose Fiction (n. 19 above), p. 152.

144 R-H, p. 144 (I.8.5). See Invernizzi, 'L'Argenis' (n. 20 above), p. 74 n. 84.

145 R-H, p. 112 (I.2.5).
} 
('prementis vitia') in order to gain support. ${ }^{146}$ Such concerns feed into the novel's function as a site for discourse about areas such as behaviour and practical ethics at court, areas pertinent to a practising diplomat, courtier, and political writer like Barclay himself. As someone who frequented court circles, who had engaged in diplomacy, and who had experience of seeking patronage, Barclay would have been familiar with dissimulation, double-speak, and the possibility of subtext under a veneer of flattery, nor would he have necessarily viewed these negatively. With his experience of moving between religious, political, and cultural systems, Barclay would have seen the benefits of guarded or ambiguous speech both for rulers and subjects - and in this latter group, we may include writers (as we have seen, the Argenis comments on the need for care and ambiguity in the discussion of Nicopompus's 'grand fiction' and notes the difficulty of critiquing and correcting rulers). ${ }^{147}$ It is of no surprise that the Argenis depicts the dissimulation, for good or for ill, involved in the efforts of those who hope to attain or retain power or those who engage with powerful men.

To conclude, the camp scene showcases the Argenis' interest in the interpretative process as the characters ask questions, provide answers, and give changing views. This is part of a drive in the novel to pose interpretative challenges to its readers, to force them to judge, assess and reassess. Just as the Argenis exploits the dialogue form in its debates on topics like politics and religion, so it exploits Sicily's potential for oppositional approaches. The choice of this island as a location allows Barclay to bring together competing scientific and mythological debates on the origins of volcanic activity and palaeontological remains. The reader is forced to interpret, to gauge the presentation of different traditions and the consequent contribution to character portrayal. In the camp scene, as elsewhere, Barclay uses the actions and words of Meleander in order to help examine the qualities of the ideal absolute ruler. The episode provides evidence of Meleander's credulity, against the view of Christie. It reveals that he is capable of being manipulated by the priests and easily swayed away from a scientific point of view. Since he is entertaining someone who poses a threat to his kingdom, having entrusted the business of the camp elsewhere, he is also shown to be insufficiently alert for one of his position. In terms of the debate about divine providence, we have seen that Barclay's presentation of volcanic activity in Sicily does not support this idea. Neither in this episode nor in the novel as a whole do we find evidence of divine intervention in human affairs: claims of divine involvement from characters do not prove that it exists. ${ }^{148}$ Nor do we find the gods overseeing a future which

\footnotetext{
146 On dissimulation, see Christie, 'Dissimulating Romance' (n. 20 above), pp. 146-59.

147 For the need for care and ambiguity in Nicopompus's project, see n. 125 above. For correction of rulers, see n. 108 above. With regard to some issues, the work arguably cultivates openness of interpretation, practicing what it preaches; see Salzman, Literary Culture (n. 123 above), p. 77; Mohamed, Sovereignty (n. 70 above), p. 64, on the Hyperephanii.

148 See IV.10.8 (R-H 678), Gobryas's assertion that things happen by the will of the gods.
} 
could thus be subject to religious predictions, whatever may be asserted by characters. ${ }^{149}$ Such a controlled framework would, indeed, go against the novel's interest in the potentiality of interpretation. ${ }^{150}$

Open Access This article is licensed under a Creative Commons Attribution 4.0 International License, which permits use, sharing, adaptation, distribution and reproduction in any medium or format, as long as you give appropriate credit to the original author(s) and the source, provide a link to the Creative Commons licence, and indicate if changes were made. The images or other third party material in this article are included in the article's Creative Commons licence, unless indicated otherwise in a credit line to the material. If material is not included in the article's Creative Commons licence and your intended use is not permitted by statutory regulation or exceeds the permitted use, you will need to obtain permission directly from the copyright holder. To view a copy of this licence, visit http://creativecommons.org/ licenses/by/4.0\%.

Publisher's Note Springer Nature remains neutral with regard to jurisdictional claims in published maps and institutional affiliations.

${ }_{149}$ As when the priest asserts that Jupiter has knowledge of all things that are to come: R-H, p. 652 (IV.7.8).

150 Many thanks to the referees for their helpful comments on this paper. 